\title{
ANALISIS MUATAN IPA MATERI POKOK SUMBER ENERGI PADA BUKU TEKS PELAJARAN TEMATIK TERPADU MI KELAS IV TEMA 2
}

\author{
Ratna Prilianti \\ ratna prilianti@gmail.com \\ Ahli Muda pada Balai Diklat Keagamaan Semarang
}

\begin{abstract}
Abstrak
Karya tulis ilmiah ini bertujuan untuk menganalisis muatan IPA materi pokok sumber energi pada buku teks pelajaran tematik terpadu SD kelas IV tema 2 "Selalu BerhematEnergi". Hasil kajian ini dapat dipergunakan sebagai referensi penggunaan dan revisi buku guru dan buku siswa Kurikulum 2013, terutama pada muatan IPA. Tujuan kajian ini adalah untuk menganalisis keberadaan muatan IPA pada buku guru dan buku siswa kelas IV tema 2 untuk subtema 1, 2, dan 3 berdasarkan Kompetensi Inti (KI) dan Kompetensi Dasar (KD); Kajian ini menggunakan dasar lampiran Permendikbud Nomor 24 Tahun 2016 tentang Kompetensi Inti dan Kompetensi Dasar untuk menganalisis keberadaan muatan IPA. Pada kajian ini ditemukan beberapa hal, yaitu (1) muatan IPA hampir ada pada setiap pembelajaran, baik tertulis maupun tidak tertulis pada KD, dari $16 \mathrm{kali}$ pertemuan di tema 2 ini, muatan IPA ada dalam 14 kali pertemuan; (2) materi tentang energi alternatifnuklir belum dibahas di dalam buku teks pelajaran.
\end{abstract}

Kata kunci: analisis, muatan IPA, buku guru, buku siswa, Kurikulum 2013

\section{Abstract}

The aim of this scientific paper is to analyze the Science content on main material of energy sorce in lesson textbook of integrated thematic for IV grade of MI (theme 2: "Selalu Berhemat Energi"). The results of this study can be used as a reference and teacher book revision and students' books in Curriculum 2013, especially on Science content. The purpose 
of this study is to analyze the presence of Science content on teacher book and student bookfor IV grade themes 1, 2, and 3 based on Core Competence (Kompetensi Inti/KI) and the Basic Competence (Kompetensi Dasar/KD). This study use basic attachment of Permendikbud No. 242016 about Core Competence and Basic Competence to analyze the existence of the Science content. In this study there are found some things, they are (1) Science content almost in every lesson, both written and unwritten on KD, of 16 meetings in this theme 2, Science content in 14 meetings; (2) material about nuclear alternative energy not discuss yet in textbooks.

Keywords: Analysis, Science Content, Teacher Books, Student Books, Curriculum 2013

\section{A. Pendahuluan}

Pendidikan di Indonesia pada tahun 2013 mengalami suatu perubahan, karena pada tahun pelajaran 2013/2014 pemerintah melalui amanatnya di Permendikbud 81A Tahun 2013 menyatakan bahwa Implementasi kurikulum pada sekolah dasar/madrasah ibtidaiyah (SD/MI), sekolah menengah pertama/madrasah tsanawiyah (SMP/MTs), sekolah menengah atas/madrasah aliyah (SMA/MA), dan sekolah menengah kejuruan/madrasah aliyah kejuruan (SMK/MAK) dilakukan secara bertahap mulai tahun pelajaran 2013/20141. Pemberlakuan kurikulum 2013 pada Kementerian Agamapun dilakukan secara bertahap diawali dari tahun pelajaran 2014/2015 terdapat 837

1 Peraturan Menteri Pendidikan Dan Kebudayaan Republik Indonesia Nomor 81A Tahun 2013, Implementasi Kurikulum, (Jakarta: Kemendikbud, 2013), hlm.3 
Madrasah se Indonesia yang melaksanakan Kurikulum $2013^{2}$. Tahun ajaran berikutnya yaitu tahun 2015/2016 ada tambahan 13.681 Madrasah pelaksana kurikulum $2013^{3}$ dan pada Tahun Pelajaran 2016/2016 pada Kementerian Agama yang ditetapkan dalam SK Dirjen Pendis Nomor 3932 Tahun 2016 yang ditandatangani pada 18 Juni 2016 adalah sebanyak 13.616 madrasah ${ }^{4}$. Madrasah tersebut meliputi Madrasah Ibtidaiyah (MI), Madrasah Tsanawiyah (MTs), dan Madrasah Aliyah (MA) di seluruh Indonesia. Balai Diklat Keagamaan Semarang yang merupakan lembaga kediklatan milik Kementerian Agama memiliki daerah kerja di Provinsi D.I. Yogyakarta dan Provinsi Jawa Tengah. Madrasah pelaksana kurikulum 2013 di Prov. D.I.Yogyakarta adalah 229 Madrasah dan Provinsi Jawa Tengah 808 Madrasah. Sebagian madrasah pelaksana kurikulum 2013 di Kementerian Agama adalah Madrasah Ibtidiyah.

Kurikulum 2013 berbeda dengan kurikulum sebelumnya yaitu KTSP 2006 dilihat dari aspek Standar Kompetensi Lulusan (SKL), Standar Isi (SI), Standar Proses dan Standar Penilaian. SKL pada Kurikulum 2013 adalah kriteria mengenai kualifikasi kemampuan lulusan yang mencakup sikap, pengetahuan, dan keterampilan. SKL dimensi sikap untuk jenjang SD/MI adalah memiliki perilaku yang mencerminkan sikap(1) beriman dan

2 Keputusan Dirjen Pendis No 481 Tahun 2015, Penetapan Madrasah Pendampingan Implementasi Kurikulum 2013, (Jakarta: Kemenag, 2015), hlm.18

3 Keputusan Dirjen Pendis No 5114 Tahun 2015, Penetapan Madrasah Pelaksana Kurikulum 2013 Tahun Pelajaran 2015-2016, (Jakarta: Kemenag, 2015), hlm.244

4 Keputusan Dirjen Pendis No 3932 Tahun 2016, Penetapan Madrasah Pelaksana Kurikulum 2013 Tahun Pelajaran 2016-2017, (Jakarta: Kemenag, 2016), hlm.223 
bertakwa kepada Tuhan YME, (2) berkarakter, jujur, dan peduli, (3) bertanggungjawab, (4) pembelajar sejati sepanjang hayat, dan (5) sehat jasmani dan rohani sesuai dengan perkembangan anak di lingkungan keluarga, sekolah, masyarakat dan lingkungan alam sekitar, bangsa, dan negara. SKL dimensi pengetahuan untuk tingkat SD/MI adalah memiliki pengetahuan faktual, konseptual, prosedural, dan metakognitif pada tingkat dasar berkenaan dengan (1) ilmu pengetahuan, (2) teknologi, (3) seni, dan (4) budaya dan mengaitkan pengetahuan dalam konteks diri sendiri, keluarga, sekolah, masyarakat dan lingkungan alam sekitar, bangsa, dan negara. Sedangkan SKL dimensi ketrampilan adalah memiliki keterampilan berpikir dan bertindak (1) kreatif, (2) produktif, (3) kritis, (4) mandiri, (5) kolaboratif, dan (6) komunikatif melalui pendekatan ilmiah sesuai dengan tahap perkembangan anak yang relevan dengan tugas yang diberikan ${ }^{5}$.

Perubahan pada standar isi kurikulum 2013 adalah adanya keterkaitan antara kompetensi dasar dari kompetensi inti 3 (aspek pengetahuan) dan kompetensi dasar dari kompetensi inti 4 (aspek ketrampilan). Perubahan pada aspek Standar Proses terutama untuk jenjang Madrasah Ibtidiyah adalah proses pembelajaran yang menggunakan model pembelajaran Tematik. Pembelajaran tematik merupakan salah satu model pembelajaran terpadu yang menggunakan tema untuk mengaitkan beberapa mata pelajaran sehingga dapat memberikan pengalaman bermakna bagi peserta didik. Pembelajaran terpadu didefinisikan

5 Lampiran Permendikbud No 20 Tahun 2016, Standar Kompetensi Lulusan, (Jakarta: Kemendikbud, 2016), hlm. 4-8 
sebagai pembelajaran yang menghubungkan berbagai gagasan, konsep, keterampilan, sikap, dan nilai, baik antar mata pelajaran maupun dalam satu mata pelajaran. Pembelajaran tematik memberi penekanan pada pemilihan suatu tema yang spesifik yang sesuai dengan materi pelajaran, untuk mengajar satu atau beberapa konsep yang memadukan berbagai informasi melalui pendekatan ilmiah sesuai dengan tahap perkembangan anak yang relevan dengan tugas yang diberikan6.

Kurikulum 2013 menyajikan bahan ajar tematik yang diwujudkan dalam bentuk buku teks untuk guru dan peserta didik. Buku teks digunakan sebagai penerapan dan pengembangan dari instructional design yang lebih menekankan pada prinsip-prinsip yang diadopsi dari teori dan temuan penelitian tentang belajar ${ }^{7}$. Buku teks memuat urutan pembelajaran yang dinyatakan dalam kegiatan-kegiatan yang harus dilakukan oleh peserta didik bersama guru untuk mencapai kompetensi tertentu, yang menjabarkan usaha minimal yang harus dilakukan peserta didik untuk mencapai kompetensi sesuai dengan kurikulum 2013 dengan berbagai kegiatan yang telah disediakan.

Buku teks terdiri atas buku guru dan buku siswa yang saling berkaitan. Oleh karena itu, buku teks harus dapat menyajikan bahan pembelajaran yang bermakna bagi peserta didik sebagai subjek belajar dan guru sebagai pendidik. Buku Panduan Guru memiliki dua fungsi, yaitu sebagai petunjuk penggunaan buku

6 Lampiran III Permendikbud No 57 Tahun 2015, PMP Tematik Terpadu, (Jakarta: Kemendikbud, 2015), hlm. 244

7 Hamzah Uno, Model Pembelajaran: Menciptakan Proses Belajar Mengajar yang Kreati dan Efektif, (Jakarta: Bumi Aksara, 2010), hlm.147 
peserta didik dan sebagai acuan kegiatan pembelajaran di kelas. Buku guru merupakan pedoman yang memuat strategi pembelajaran, metode pembelajaran, teknik pembelajaran, dan penilaian untuk setiap mata pelajaran dan/atau tema pembelajaran. Sedangkan buku siswa merupakan buku panduan sekaligus buku aktivitas yang akan memudahkan para siswa terlibat aktif dalam pembelajaran. Buku Siswa dilengkapi dengan penjelasan lebih rinci tentang isi dan penggunaan buku sebagaimana dituangkan dalam Buku Panduan Guru. Buku siswa menjabarkan usaha minimal yang harus dilakukan peserta didik untuk mencapai kompetensi yang diharapkan. Dalam proses belajar, peserta didik dipacu untuk mencari dari sumber belajar lain yang tersedia dan terbentang luas di sekitarnya.

Buku teks didesain menggunakan pendekatan ilmiah (scientific approach), yang merupakan proses pembelajaran pada implementasi kurikulum 2013. Proses pembelajaran sangat erat hubungannya dengan penilaian dan tujuan, maka pada kurikulum 2013 digunakan penilaian autentik (authentic assessment) untuk mengetahui ketercapaian indikator yang diturunkan dari Kompetensi Inti (KI) dan Kompetensi Dasar (KD). Oleh karena itu, buku teks hendaknya memuat tujuan, proses dan penilaian tersebut agar dapat membantu guru dalam implementasi Kurikulum 2013. IPA merupakan salah satu mata pelajaran yang turut berperan penting dalam pendidikan sikap, pengetahuan dan keterampilan sejak dini bagi anak. IPA berperan serta dalam pembentukan kepribadian, keterampilan dan perkembangan intelektual siswa. Pada hakikatnya, IPA dapat dipandang dari tiga 
dimensi yaitu IPA sebagai proses, IPA sebagai produk dan pengembangan sikap ${ }^{8}$.

IPA sebagai proses yaitu siswa diharapkan memiliki kemampuan untuk mengembangkan pengetahuan, gagasan, dan menerapkan konsep yang diperolehnya untuk menjelaskan masalah dan memecahkan masalah dalam kehidupan seharihari. Dari segi produk, siswa diharapkan dapat memahami konsepkonsep sains dan keterkaitannya dengan kehidupan sehari-hari. Dipandang dari segi sikap, siswa diharapkan mempunyai minat untuk mmpelajari benda-benda di lingkungannya, bersikap ingin tahu, tekun, kritis, mawas diri, bertanggung jawab. Hal ini sejalan dengan yang dikatakan oleh Andrian ${ }^{9}$ bahwa belajar dalam Ilmu Pengetahuan Alam bukan merupakan proses penghafalan katakata yang bermakna saja melainkan asosiasiasi pengalamanpengalaman. Berdasarkan beberapa hal yang telah dijelaskan diatas, maka dalam rangka optimalisasi implementasi Kurikulum 2013, maka diperlukan adanya analisis isi atau analisis konten muatan IPA buku guru dan buku siswa untuk melihat kesesuaian dengan tuntutan Kurikulum 2013.

\section{B. Metode Penelitian}

Metode yang digunakan dalam penelitian ini adalah metode penelitian deskriptif, yaitu metode yang membicarakan beberapa kemungkinan untuk memecahkan masalah aktual dengan jalan

8 Trianto, Model Pembelajaran Terpadu, (Jakarta: Kencana, 2010), hlm.137

9 Andrian, Panduan Pendidik Media Pendidikan IPA Membuat Muridku Pintar, (Bekasi: Ganeca Exact, 2010), hlm. 16 
mengumpulkan data, menyusun atau mengklasifikasi, menganalisis, dan menginterpretasikannya. Metode deskriptif analisis dilakukan dengan cara mendeskripsikan fakta-fakta yang kemudian disusul dengan analisis, tidak semata-mata menguraikan, melainkan juga memberikan pemahaman dan penjelasan secukupnya ${ }^{10}$. Alasan penulis menggunakan metode ini adalah karena pada dasarnya penelitian ini merupakan penelitian kualitatif. Selain itu, metode ini dianggap cukup tepat untuk melakukan pendekatan terhadap masalah yang akan diteliti.

Teknik yang dilakukan untuk mengumpulkan data dalam penelitian ini adalah dengan studi kepustakaan yang merupakan suatu teknik pengumpulan data dengan menghimpun dan menganalisis dokumen-dokumen, baik dokumen tertulis, gambar, maupun elektronik. Dokumen yang dihimpun dan dianalisis datanya adalah peraturan-peraturan yang terkait dengan kurikulum 2013, buku guru dan buku siswa.

\section{Hasil dan Pembahasan}

Buku Guru (BG) dan Buku Siswa (BS) yang dikaji dalam penelitian ini adalah BG dan BS edisi revisi Tahun 2016, Buku Guru sebagai buku pedoman guru melaksanakan proses pembelajaran di kelas dalam pelaksanaan Kurikulum 2013. Oleh karena itu, buku tersebut harus disesuaikan dengan amanat Kurikulum 2013. Analisis dilakukan dengan mencocokkan antara Kompetensi Inti (KI) dan Kompetensi Dasar (KD) yang tercantum

10 Ratna, Nyoman Kutha, Metodologi Penelitian: Kajian Budaya dan Ilmu Sosial Humaniora Pada Umumnya, (Yogyakarta: Pustaka Pelajar, 2010), hlm.53 
pada Permendikbud Nomor 24 Tahun 2014 tentang Kompetensi Inti dan Kompetensi Dasar Pelajaran pada Kurikulum Kurikulum 2013 pada Pendidikan Dasar dan Pendidikan Menengah. KI dan KD IPA pada kelas IV tercantum pada lampiran $24^{11}$ dengan KI dan KD yang tercantum pada Buku Guru. Selain itu, juga mencocokkan KI dan KD materi IPA yang berkaitan dengan tujuan yang tercantum pada buku guru dan materi IPA pada buku siswa. Hasil analisis yang dilakukan terhadap SKL yang tertuang dalam Buku Guru adalah belum dituliskan SKL di dalam BG yang sesuai dengan Permendikbud No 20 Tahun 2016. Solusi yang dilakukan oleh guru madrasah ketika akan melihat SKL adalah berpedoman pada Permendikbud 2015/2016.

Kompetensi inti yang dituliskan di dalam buku guru halaman viii belum sesuai dengan Permendikbud 24/2016.

\section{KOMPETENSI INTI KELAS IV}

\begin{tabular}{|l|}
\hline 1. Menerima dan menjalankan ajaran agama yang dianutnya. \\
\hline 2. Menunjukkan perilaku jujur, disiplin, tanggung jawab, santun, peduli, dan percaya \\
diri dalam berinteraksi dengan keluarga, teman, guru dan tetangga.
\end{tabular}

Gambar 1. KI yang tertuang di dalam Buku Guru

Perubahan kompetensi inti yang tertuang pada permendikbud 24/2016 adalah KI 1 (aspek sikap spiritual) dan KI 2 (aspek sikap

11 Lampiran Permendikbud 24 Tahun 2016, Kompetensi Inti dan Kompetensi Dasar IPA SD/MI, (Jakarta : Kemendikbud, 2016), hlm.3 
sosial) hanya ada pada mata pelajaran PKn dan Pendidikan Agama. Untuk mata pelajaran selain PKn dan Pendidikan Agama tidak terdapat KI 1 dan KI 2. Sehingga KD dari KI 1 dan KI 2 pun hanya ada pada mata pelajaran PKn dan Pendidikan Agama. Pada pembelajaran tematik terdapat perpaduan beberapa mata pelajaran, sehingga untuk menuliskan kompetensi inti yang kita jadikan dasar adalah kompetensi inti yang ada pada mata pelajaran PKn yang bunyinya berdasarkan lampiran 18 Permendikbud No 24/2016 adalah sebagai berikut: (1) Menerima, menjalankan, dan menghargai ajaran agama yang dianutnya, (2) Menunjukkan perilaku jujur, disiplin, tanggung jawab, santun, peduli, dan percaya diri dalam berinteraksi dengan keluarga, teman, guru, dan tetangganya, (3) Memahami pengetahuan faktual dengan cara mengamati [mendengar, melihat, membaca] dan menanya berdasarkan rasa ingin tahu tentang dirinya, makhluk ciptaan Tuhan dan kegiatannya, dan benda-benda yang dijumpainya di rumah dan di sekolah, (4) Menyajikan pengetahuan faktual dalam bahasa yang jelas dan logis, dalam karya yang estetis, dalam gerakan yang mencerminkan anak sehat, dan dalam tindakan yang mencerminkan perilaku anak beriman dan berakhlak mulia.

Materi IPA pada kelas tinggi, yaitu kelas 4, 5, dan 6 sudah berdiri sendiri sebagai satu mata pelajaran khusus yaitu Ilmu Pengetahuan Alam (IPA) berbeda pada kelas rendah yaitu kelas 1,2,3 yang materi IPA nya terintegrasi menjadi satu dengan mata pelajaran PKn dan Bahasa Indonesia, sehingga di kelas rendah tidak terdapat mata pelajaran IPA. Lingkup materi mata pelajaran 
IPA pun sudah tercantum di dalam Permendikbud 21/2016. Buku teks Tema 2 Selalu Berhemat Energi pada Kelas IV SD/MI merupakan salah satu tema dengan materi intinya adalah mata pelajaran IPA. Tema 2 terbagi menjadi 3 subtema, yaitu subtema 1 Sumber Energi, subtema 2 Manfaat Energi dan subtema 3 Energi Alternatif. Ketiga subtema dalam tema 2 juga mencantumkan materi IPA materi pokok sumber energi. Materi tersebut tersebar dalam 6 kali kegiatan pembelajaran dalam setiap sub temanya.

Analisis secara mendalam dilakukan untuk melihat keberadaaan materi IPA yang sudah dikemas menjadi tematik terpadu dengan materi lain seperti IPS, PJOK, SBdP, PPKn, Bahasa Indonesia, dan Matematika. Analisis keberadaan muatan IPA ini diperlukan karena jika dilihat dari KD 3.5 yang berbunyi mengidentifikasi berbagai sumber energi, perubahan bentuk energi dan sumber energi alternatif (angin, air, matahari, panas bumi, bahan bakar organik, dan nuklir) dalam kehiduan seharihari dan dan KD 4.5 Menyajikan laporan hasil pengamatan dan peneusuran informasi tentang berbagai bentuk energi, secara umum materi IPA mendominasi pada tema ini, akan tetapi justru pada beberapa pembelajaran tidak tercantum KD IPA. Hasil analisis dapat ditunjukkan dengan tabel berikut.

Tabel 1. Hasil Analisis Muatan IPA dalam BG dan BS

\begin{tabular}{|l|c|c|c|c|}
\hline \multicolumn{1}{|c|}{$\begin{array}{c}\text { Sub Tema/ } \\
\text { Pembelajaran }\end{array}$} & \multicolumn{2}{|c|}{ KD IPA dalam BG } & \multicolumn{2}{c|}{ Muatan IPA dalam BS } \\
\cline { 2 - 5 } & Ada & Tidak Ada & Ada & Tidak Ada \\
\hline Sub Tema 1 & & & & \\
$1 . \quad \mathrm{Pb} 1$ & $\mathrm{~V}$ & - & $\mathrm{V}$ & - \\
$2 . \quad \mathrm{Pb} 2$ & - & $\mathrm{V}$ & $\mathrm{V}$ & - \\
$3 . \quad \mathrm{Pb} 3$ & $\mathrm{~V}$ & - & $\mathrm{V}$ & - \\
\hline
\end{tabular}




\begin{tabular}{|c|c|c|c|c|}
\hline \multirow{2}{*}{$\begin{array}{c}\text { Sub Tema/ } \\
\text { Pembelajaran }\end{array}$} & \multicolumn{2}{|c|}{ KD IPA dalam BG } & \multicolumn{2}{|c|}{ Muatan IPA dalam BS } \\
\hline & Ada & Tidak Ada & Ada & Tidak Ada \\
\hline 4. $\mathrm{Pb} 4$ & - & $\mathrm{V}$ & $\mathrm{V}$ & - \\
\hline 5. $\mathrm{Pb} 5$ & - & V & V & - \\
\hline 6. $\mathrm{Pb} 6$ & - & V & V & - \\
\hline Sub Tema 2 & & & & \\
\hline 1. $\mathrm{Pb} 1$ & V & - & V & - \\
\hline 2. $\mathrm{Pb} 2$ & - & V & - & V \\
\hline 3. $\mathrm{Pb} 3$ & V & - & V & - \\
\hline 4. $\mathrm{Pb} 4$ & - & V & - & V \\
\hline 5. $\mathrm{Pb} 5$ & - & V & V & - \\
\hline 6. $\mathrm{Pb} 6$ & - & $\mathrm{V}$ & - & V \\
\hline Sub Tema 3 & & & & \\
\hline 1. $\mathrm{Pb} 1$ & $\mathrm{~V}$ & - & V & - \\
\hline 2. $\mathrm{Pb} 2$ & - & V & V & - \\
\hline 3. $\mathrm{Pb} 3$ & V & - & V & - \\
\hline 4. $\mathrm{Pb} 4$ & - & V & - & V \\
\hline 5. $\mathrm{Pb} 5$ & - & V & V & - \\
\hline 6. $\mathrm{Pb} 6$ & - & $\mathrm{V}$ & $\mathrm{V}$ & - \\
\hline
\end{tabular}

Pada sub tema 1 pembelajaran 1 tujuan pembelajaran yang bermuatan mapel IPA adalah: (1) dengan percobaan, siswa mampu menjelaskan manfaat energi matahari dalam kehidupan sehari-hari dengan tepat, (2) setelah percobaan, siswa mampu menyajikan laporan hasil pengamatan tentang perubahan bentuk energi matahari dalam kehidupan dengan sistematis. (3) dengan diskusi dan pemecahan masalah, siswa mampu mengidentifikasi sumber daya alam dan pemanfaatannya dengan tepat, serta (4) dengan diskusi dan pemecahan masalah, siswa mampu menyajikan hasil identifikasi sumber daya alam dan pemanfaatannya dalam bentuk tulisan dengan sistematis. Tujuan pembelajaran (1) metode pembelajaran yang digunakan tidak sesuai dengan yang ada di BS yaitu dengan mengamati gambar siswa mampu menjelaskan manfaat energi matahari dalam kehidupan sehari-hari dengan tepat, tidak melalui percobaan 
seperti tertuang dalam BG (halaman 1 BS). Untuk tujuan pembelajaran (2) kegiatan di dalam BS sudah sesuai melalui kegiatan ayo mencoba pada BS halaman 3. Tujuan pembelajaran (3) dan (4) kegiatan di dalam BS menjadi satu kegiatan dengan ayo berdiskusi pada halaman 6 .

Subtema 1 pembelajaran 2 di dalam pemetaan BG hal 15 dan pada tujuan pembelajaran serta langkah-langkah pembelajaran tidak menggambarkan adanya muatan IPA dalam pembelajaran 2 ini. Namun, pada BS halaman 11 pada kegiatan ayo mengamati ada muatan IPA yaitu tentang energi air, seperti terlihat pada gambar di bawah ini:

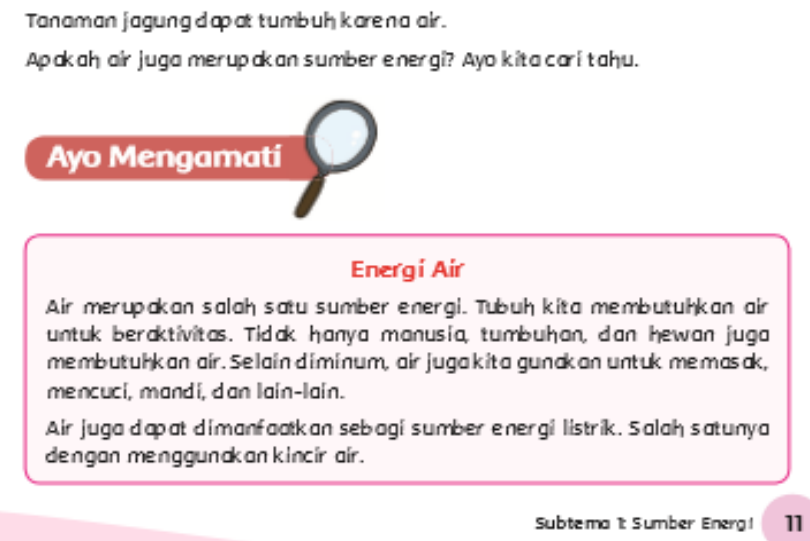

Gambar 2. Temuan muatan IPA pada Subtema 1 Pembelajaran 2

Selain itu, materi IPA juga "menumpang" pada mata pelajaran Bahasa Indonesia tentang menuliskan kembali informasi dari teks "Energi Air" yang berkaitan dengan nergi alternatif di KD IPA (Buku Siswa hal 11). Pada pembelajaran 3 tujuan pembelajaran yang bermuatan IPA adalah (1) dengan percobaan, 
siswa mampu mengidentifikasi perubahan bentuk energi angin dalam kehidupan sehari-hari dengan tepat, dan (2) dengan percobaan, siswa mampu menyajikan laporan hasil pengamatan tentang perubahan bentuk energi angin menggunakan kosakata baku dan kalimat efektif dengan sistematis. Kegiatan yang sesuai dengan tujuan pembelajaran tertuang di dalam BS ada dalam kegiatan ayo mencoba di halaman 22 dan ayo menulis halaman 24 .

Pada subtema 1 pembelajaran 4 di dalam pemetaan BG hal 34 dan pada tujuan pembelajaran serta langkah-langkah pembelajaran tidak menggambarkan adanya muatan IPA dalam pembelajaran 4 ini. Namun, pada BS halaman 28 pada kegiatan ayo berdiskusi ada muatan IPA yaitu tentang energi listrik, seperti terlihat dalam gambar di bawah ini.

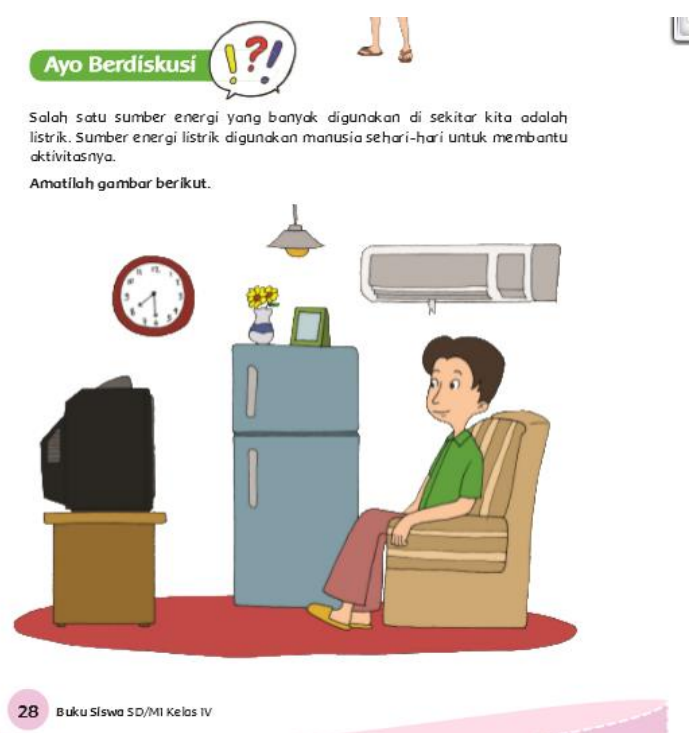

Gambar 3. Temuan muatan IPA pada Subtema 1 Pembelajaran 4 
Pembelajaran 5 subtema 1 di dalam pemetaan BG halaman 42 tidak menggambarkan adanya muatan IPA dalam pembelajaran 5 ini, tetapi pada BS halaman 37 pada kegiatan ayo mengamati ada muatan IPA yaitu tentang sumber energi alami. Bukti yang nyata terlihat dari gambar di bawah ini:

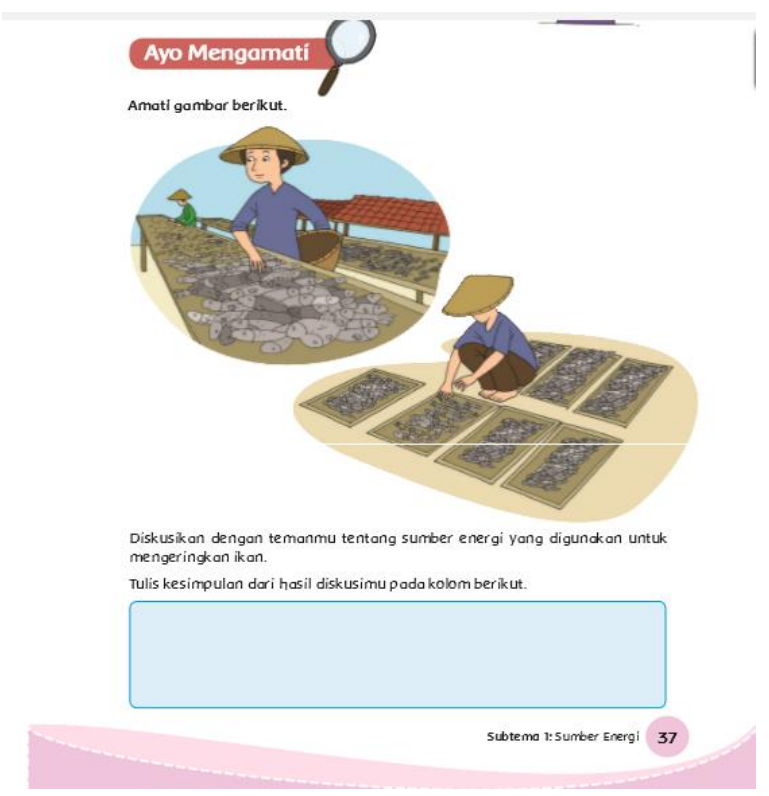

Gambar 4. Temuan muatan IPA pada Subtema 1 Pembelajaran 5

Dalam pemataan KD di pembelajaran ke 6 tidak ada muatan IPA, namun pada BS halaman 42 pada kegiatan berdiskusi dan pada kegiatan ayo membaca halaman 44 terdapat muatan IPA yaitu tentang minyak bumi.

Subtema 2 pembelajaran 1, pada pemetaan halaman 57 BG penulisan KD 3.5 belum sesuai dengan Permendikbud 24/2016, seharusnya kata kerja yang digunakan mengidentifikasi bukan 
memahami. Temuan perbedaan pada BG dan regulasi terlihat pada gambar di bawah ini:

Pembelajaran 1

Pemetaan Kompetensi Dasar dalam Pembelajaran

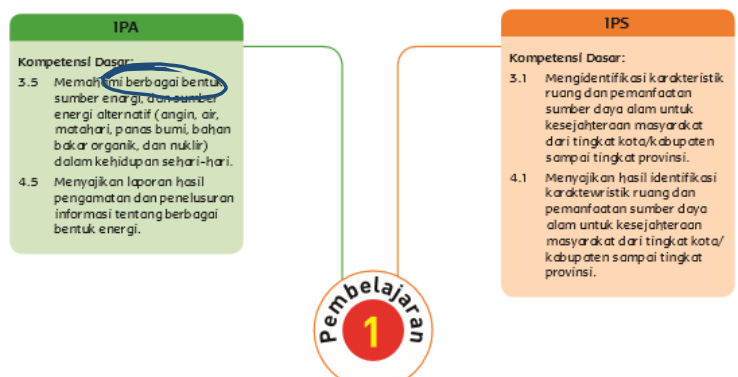

Gambar 5. Temuan perbedaan KD 3.3 pada BG dengan

Permendikbud 24/2016

Tujuan pembelajaran pada subtema $2 \mathrm{~Pb} 1$ yang bermuatan IPA adalah (1) dengan pengamatan, siswa mampu mengidentifikasi manfaat perubahan bentuk energi dalam kehidupan sehari-hari dengan tepat dan (2) setelah pengamatan, siswa mampu menyajikan laporan hasil pengamatan tentang berbagai perubahan bentuk energi dalam kehidupan sehari-hari dengan sistematis. Tujuan pembelajaran tersebut dapat dicapai melalui kegiatan pembelajaran pada pembelajaran 1 subtema 2 ini terdapat dalam BS pada kegiatan ayo mencoba pada halaman 53. Pada pembelajaran ke 2, 4, dan 6 pada subtema 2 pada pemetaan KD tidak terdapat muatan IPA, begitu pula pada BS nya, sehingga sudah sesuai antara BG dan BS. Pada pembelajaran 5 
yang dalam pemetaan tidak ada muatan IPA, ternyata dalam buku siswa hal 84 pada kegiatan ayo mengamati terdapat muatan IPA materi tentang batubara, terlihat dari gambar berikut ini.

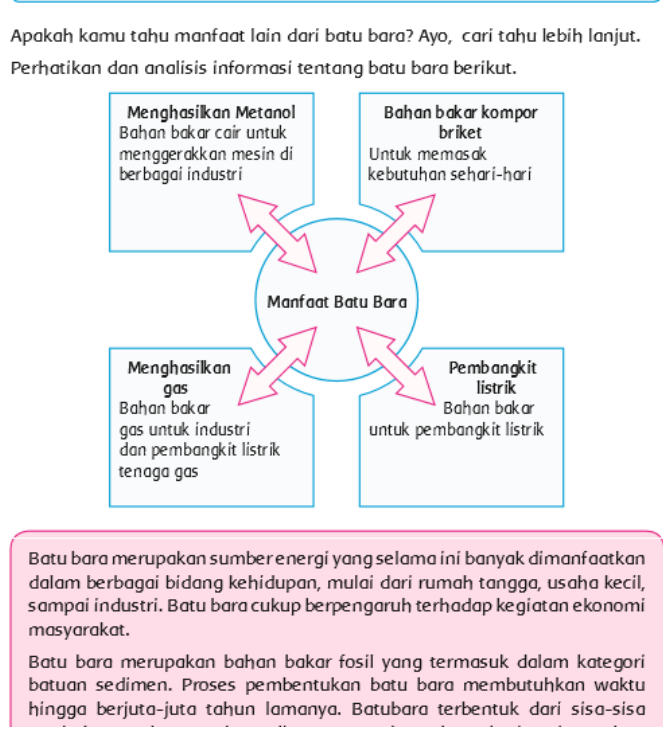

Gambar 6. Temuan muatan IPA pada Subtema 2 Pembelajaran 5

Pada subtema 3 pembelajaran 1 tujuan pembelajaran yang bermuatan IPA adalah (1) dengan pengamatan, siswa mampu mengidentifikasi manfaat energi alternatif dalam kehidupan sehari-hari dengan tepat, (2) setelah pengamatan, siswa mampu menyajikan laporan dalam bentuk peta pikiran hasil pengamatan tentang perubahan bentuk energi alternatif dalam kehidupan sehari-hari dengan sistematis. Dalam BS metode yang digunakan tidak dengan mengamati tetapi dengan membaca seperti terlihat dalam halaman 98. Pembelajaran 2 subtema 3 pada pemetaan tidak terdapat KD mata pelajaran IPA, namun dalam BS halaman 
102 pada kegiatan berdiskusi terdapat muatan IPA penggunaan energi alternatif. Pada pembelajaran 3 subtema 3 ini dalam pemetaan sudah terdapat muatan IPA dan di dalam BS nya pun sudah memfasilitasi kegiatan percobaan dalam kegiatan ayo membaca dan menulis di halaman 115 tentang energi pengganti energi listrik. Pembelajaran 4 subtema 3 tidak terdapat dalam pemetaan KD di dalam BG dan di dalam buku siswapun tidak menunjukkan adanya muatan IPA, sehingga dapat dinyatakan sesuai antara BG dan BS. Pembelajaran 5 subtema 3 pun walaupun di dalam pemetaan KD tidak terdapat muatan mapel IPA, namun pada kenyataan di dalam BS halaman 126 pada kegiatan ayo berlatih terdapat muatan IPA tentang enegri alternatif dari singkong, seperti terlihat pada gambar di bawah ini:

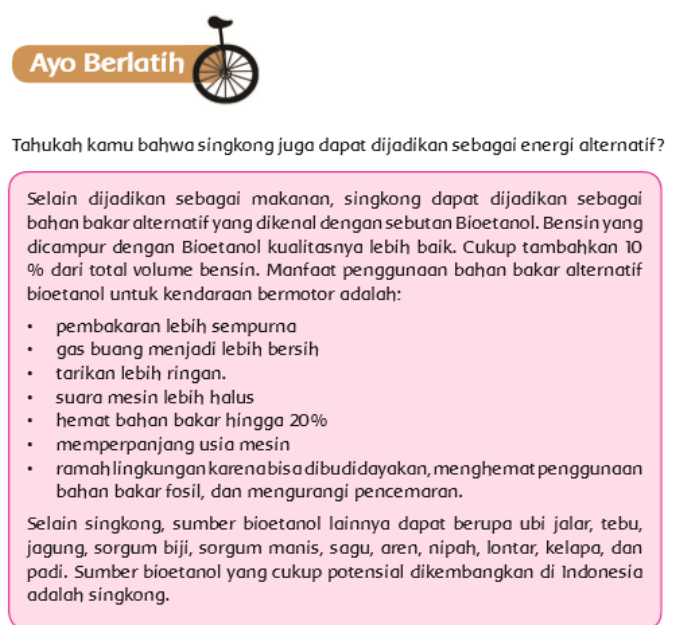

Gambar 7. Temuan muatan IPA pada Subtema 3 Pembelajaran 5

Muatan IPA yang di dalam pemetaan BG tidak terdapat pada pemebelajaran 6 subtema 3 ini, termyata di dalam BS masih 
terdapat muatan IPA, yang terlihat pada halaman 131 tentang energi alternatif, seperti pada gambar di bawah ini:

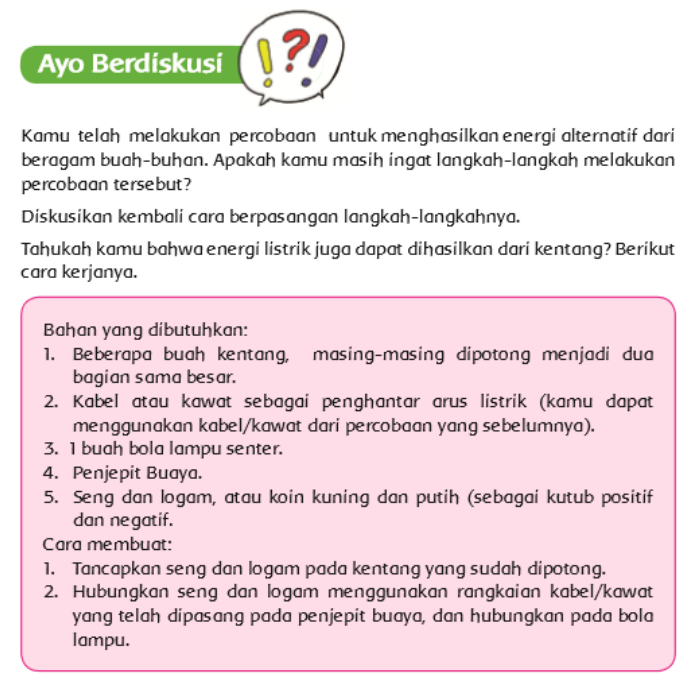

Gambar 7. Temuan muatan IPA pada Subtema 3 Pembelajaran 6

Dari hasil analisis muatan IPA pada buku siswa dapat kita ketahui dari 18 kali pembelajaran pada tema 3 selalu berhemat energi, 14 kali pertemuan terdapat muatan IPA dan hanya 4 kali pertemuan saja yang terdapat muatan IPA. Di dalam pemetaan KD di dalam BG hanya 6 kali pertemuan saja muatan IPA muncul. Solusi yang dapat dilakukan oleh guru adalah melakukan permusan indikator terlebih dahulu sehingga seluruh materi yang terdapat dalam kompetensi dasar dapat tersampaikan semuanya melalui proses pembelajaran yang menyenangkan dengan pembelajaran tematik. Dalam buku siswa tema 3 inipun belum kita temukan pembahsan materi tentang energi alternatif terutama nuklir, padahal materi pokok yang ada di dalam kd 3.5 jelas 
menyebutkan salah satu energi alternatif yang dibahas adalah energi nuklir. Oleh karena itu, guru perlu mengembangkan bahan ajar yang sudah disediakan oleh pemerintah melalui buku guru dan buku siswa pada kurikulum 2013.

\section{Simpulan}

Pada tema 2 Selalu Berhemat Energi subtema 1 Sumber Energi, subtema 2 Manfaat Energi dan subtema 3 Energi Alternatif pada Kelas IV SD/ muatan IPA hampir terdapat pada setiap kali pembelajaran. Dari total 18 kali pembelajaran tema 2 ini, hanya ada 4 pembelajaran yang tidak terdapat muatan IPA yaitu pada subtema 2 pembelajaran 2, 4, 6 dan subtema 3 pembelajaran 4 . Namun pada pemetaan KD yang terdapat dalam buku guru hanya ada 6 kali pertemuan yang bermuatan IPA yang tertulis, yang lainnya tercantum secara tidak tertulis dalam bentuk KD namun tertulis dalam kegiatan pada buku siswa. Selain itu, muatan IPA yang tidak tertulis juga berada dalam KD, tujuan pembelajaran dan kegiatan mata pelajaran lain seperti IPS dan Bahasa Indonesia. Akan tetapi, muatan IPA yang tidak tercantum lebih banyak "menumpang" pada KD Bahasa Indonesia melalui teks yang berkaitan dengan IPA, seperti teks energi air. 


\section{DAFTAR PUSTAKA}

Andrian, 2010, Panduan Pendidik Media Pendidikan IPA Membuat Muridku Pintar, Bekasi: Ganeca Exact

Hamzah Uno, 2010, Model Pembelajaran: Menciptakan Proses Belajar Mengajar yang Kreati dan Efektif, Jakarta: Bumi Aksara

Ratna, Nyoman Kutha, 2010, Metodologi Penelitian: Kajian Budaya dan Ilmu Sosial Humaniora Pada Umumnya. Yogyakarta: Pustaka Pelajar

Trianto, 2010, Model Pembelajaran Terpadu. Jakarta: Kencana

Keputusan Dirjen Pendis No 481 Tahun 2015, 2015, Penetapan Madrasah Pendampingan Implementasi Kurikulum 2013, Jakarta: Kemenag

Keputusan Dirjen Pendis No 5114 Tahun 2015, 2015, Penetapan Madrasah Pelaksana Kurikulum 2013 Tahun Pelajaran 2015-2016, Jakarta: Kemenag

Keputusan Dirjen Pendis No 3932 Tahun 2016, 2016, Penetapan Madrasah Pelaksana Kurikulum 2013 Tahun Pelajaran 2016-2017, Jakarta: Kemenag

Peraturan Menteri Pendidikan Dan Kebudayaan Republik Indonesia Nomor 81A Tahun 2013, 2013, Implementasi Kurikulum, Jakarta: Kemendikbud

Lampiran III Permendikbud No 57 Tahun 2015, 2015, PMP Tematik Terpadu, Jakarta: Kemendikbud

Lampiran Permendikbud No 20 Tahun 2016, 2016, Standar Kompetensi Lulusan, Jakarta: Kemendikbud 
Lampiran Permendikbud 24 Tahun 2016, 2016, Kompetensi Inti dan Kompetensi Dasar IPA SD/MI, Jakarta : Kemendikbud 